\title{
EFEK PROPOLIS CAIR Trigona spp. TERHADAP RESPONS IMUN TIKUS Sprague Dawley YANG DIINFEKSI Sthapylococcus aureus
}

\section{(Effects of liquid propolis of Trigona spp. on immune response of Sprague Dawley rats infected with Sthapylococcus aureus)}

\author{
Nurbani Kalsum ${ }^{1 *}$, Ahmad Sulaeman ${ }^{2}$, Budi Setiawan'2, I Wayan Teguh Wibawan ${ }^{3}$ \\ ${ }^{1}$ Jurusan Teknologi Pertanian, Politeknik Negeri Lampung, Lampung 35144 \\ ${ }^{2}$ Departemen Gizi Masyarakat, Fakultas Ekologi Manusia, Institut Pertanian Bogor, Bogor 16680 \\ ${ }^{3}$ Fakultas Kedokteran Hewan, Institut Pertanian Bogor, Bogor 16680
}

\begin{abstract}
This study aimed to evaluate the effect of liquid propolis of Trigona spp. on the immunological parameters in mice infected with Sthapylococcus aureus. The effects of propolis were analyzed using the macrophage activity as determined by the phagocytic activity and by the production of nitric oxide (NO) in Sprague Dawley rat peritoneal macrophages and the production of antibodies. The results showed that the liquid propolis produces (a) an increase in the phagocytic index, (b) a significant increase in $N O$ production, and (c) an increase over the production of IgG antibodies. This study indicates that the ethanolic extract of propolis of Trigona spp. is able to activate macrophages, promote the production of No and antibodies. The combination of these results suggests that this extract has an immunomodulatory effect and can boost the immune responsse.
\end{abstract}

Keywords: antibodies, immunomodulator, macrophages activity, propolis Trigona spp.

\begin{abstract}
ABSTRAK
Penelitian ini bertujuan untuk mengevaluasi efek pemberian propolis cair Trigona spp. terhadap parameter imunologi pada tikus yang diinfeksi Sthapylococcus aureus. Efek propolis dianalisis melalui aktivitas makrofag yang ditentukan oleh aktivitas fagositosis dan produksi Nitrit Oksida (NO) pada makrofag peritoneum tikus Sprague Dawley serta produksi antibodi. Hasil penelitian menunjukkan bahwa propolis cair menghasilkan (a) peningkatan indeks fagositik, (b) peningkatan yang signifikan produksi NO, dan (c) peningkatan produksi antibodi IgG. Studi ini menunjukkan bahwa ekstrak etanol propolis cair Trigona spp. mampu mengaktifkan makrofag, meningkatkan produksi NO dan antibodi. Kombinasi hasil ini menunjukkan bahwa ekstrak ini memiliki efek imunomodulator dan mampu meningkatkan respons imun.
\end{abstract}

Kata kunci: aktivitas makrofag, antibodi, imunomodulator, propolis Trigona spp.

\section{PENDAHULUAN}

Sistem imun merupakan lini pertama pertahanan tubuh manusia, melindunginya dari penyakit dan mengobatinya apabila telah terjadi penyakit. Tubuh manusia secara terus menerus terpejan oleh berbagai faktor yang berdampak pada melemahnya fungsi sitem imun dan meningkatkan imunosupresi. Disfungsi sistem imun tubuh bertanggung jawab untuk patofisiologi dari banyak penyakit.
Modulasi respons imun, baik dengan stimulasi sistem kekebalan tubuh atau dengan menekan reaksi imun yang tidak diinginkan, untuk meringankan penyakit tersebut, telah menarik beberapa peneliti selama bertahun-tahun. Terapi imunomodulator bisa memberikan alternatif untuk kemoterapi konvensional untuk berbagai kondisi sakit, terutama ketika mekanisme pertahanan inang harus diaktifkan pada kondisi respons imun terganggu. Penelitian terkait aplikasi imunostimulan sebagai aktivator sistem imun

"Koresponsdensi: Telp: +6281369335135, Surel: nurbanikalsum@yahoo.co.id 
hasilnya tidak meyakinkan dan perlu pencarian imunostimulan baru dari sumber baru (Naga \& Rajeshwari 2014).

Sistem pertahanan tubuh atau respons imun yang terjadi akibat adanya invasi bakteri sebagai antigen ketika masuk ke dalam tubuh akan dieliminasi oleh neutrofil dan makrofag sebagai perannya pada sistem imun innate. Respons imun seluler lebih efektif dalam mengeliminasi patogen intraseluler. Makrofag merupakan efektor utama pada respons imun seluler. Sebagai fagosit profesional, makrofag bertanggung jawab dalam memusnahkan sel yang terinfeksi patogen intraseluler, termasuk Sthapylococcus aureus (Abbas et al. 2012).

Keadaan aktivasi makrofag dan limfosit $\mathrm{T}$ dan $\mathrm{B}$ memainkan peran utama dalam patogenesis gangguan yang diperantarai imun (RieuxLaucat et al. 2003). Makrofag adalah anggota penting dari sistem kekebalan tubuh bawaan dan bersama-sama dengan neutrofil, eosinofil dan selsel NK (pembunuh alami) merupakan garis pertahanan pertama untuk mengidentifikasi, mengeliminasi atau mengandung serangan mikroorganisme dan makromolekul beracun. Makrofag kunci penting dalam pemeliharaan homeostasis jaringan dan bertanggung jawab untuk mendeteksi, melanda, dan menghancurkan patogen (Nathan \& Xie 1994; Billack 2006). Dalam merespons cidera, makrofag mengikat patogen dan mengantarkannya ke komponen lain dari kekebalan adaptif, yang dibentuk oleh antibodi dan respons yang diperantarai sel yang dilakukan oleh selsel limfosit yang berbeda, masing-masing, sel B dan sel T (Medzhitov 2001; Adereem 2001). Selama aktivasi makrofag, beberapa senyawa yang dilepaskan seperti sitokin, spesies oksigen reaktif, oksida nitrat, dan mediator inflamasi lipid, terlibat dalam respons inflamasi (Abbas et al. 2012).

Hasil penelitian Kang et al. (2011) menunjukkan asam lipoteikoat (LTA) pada bakteri gram positif tidak dapat menginduksi produksi NO pada cell line makrofag RAW 264,7 kecuali jika terdapat interferon gamma (IFN- $\gamma$ ) yang dapat meningkatkan aktivitas pengikatan DNA dari faktor transkripsi NF- $\kappa$ B yang diketahui terlibat pada ekspresi gen iNOS. Diferensiasi dan proliferasi limfosit B secara bersama-sama didorong oleh senyawa IL-6 yang dihasilkan oleh makrofag dan IL-2 yang dihasilkan oleh sel T helper. Diferensiasi limfosit B sangat penting untuk tahap perkembangan dalam mengatur jumlah immunoglobulin (Ig) yang dihasilkan (Papanicolaou 2000). Aktivasi sel B tidak hanya disebabkan oleh IL-6, tetapi juga dibantu oleh IL-4 yang berfungsi mengaktivasi sel $\mathrm{B}$ yang sedang istirahat dan IL-5 yang berfungsi memacu pertumbuhan sel B yang sudah aktif. Sitokin-sitokin inilah yang memacu sel B untuk menghasilkan antibodi (Noss et al. 2001).

Pemaparan berulang dalam jangka waktu tertentu dari imunomodulator diperlukan untuk mendapatkan limfosit T spesifik yang mensekresikan sitokin yang mampu mengaktivasi makrofag (Naga \& Rajeshwari 2014). Berdasarkan hal tersebut maka diperlukan imunomodulator yang tingkat ketersediaannya tinggi sehingga bisa diberikan berulang dalam jangka waktu panjang seperti imunomodulator yang berasal dari alam, yang salah satunya adalah propolis.

Propolis adalah produk resin yang digunakan oleh lebah pekerja untuk menutup celahcelah, mendempul retakan-retakan, memperkecil dan menutup lubang, dan komposisi kimianya tergantung pada spesies lebah dan vegetasi sumber resin (Bankova 2009). Lebih dari 300 senyawa kimia telah diidentifikasi dari propolis, termasuk polifenol (misalnya, flavonoid), kumarin, terpenoid, asam amino, mineral, dan sebagainya (Marcucci et al. 2001; Falcão et al. 2013; Shi et al. 2012; Bonvehí \& Bermejo 2013). Propolis juga mengandung banyak senyawa fenol khususnya flavonoid sehingga propolis merupakan sumber senyawa flavonoid yang baik (Mihai et al. 2011). Krol et al. (1994) menyatakan bahwa flavonoid merupakan kelompok senyawa kimia yang diketahui memiliki aktivitas antioksidan terutama kemampuannya dalam mengikat radikal bebas (free radical scavenging) dan sifat mengkelat logam (metal chelating).

Senyawa fenol yang terdapat pada tumbuhan, umumnya memiliki beragam kemampuan bioaktivitas termasuk aktivitas anti-oksidan. Produk ini telah menarik minat peneliti dalam beberapa dekade terakhir karena sifat-sifat biologis dan farmakologisnya, antara lain seperti antimikroba (Sforcin et al. 2000; Bufalo et al. 2009; Silva et al. 2012), imunomodulator (Silva et al. 2012), antiinflamasi (Silva et al. 2012), dan antioksidan (Kumazawa et al. 2004).

Salah satu spesies lebah yang potensial memproduksi propolis yang dimiliki Indonesia yaitu spesies lebah lokal Trigona spp. Berdasarkan uraian di atas, maka penelitian ini bertujuan untuk mengetahui efek ekstrak etanol propolis Trigona spp. terhadap aktivitas fagositosis dan produksi nitrit oksida makrofag peritenium tikus Sprague Dawley yang diinfeksi Staphylococcus aureus. 


\section{METODE}

\section{Desain, tempat, dan waktu}

Penelitian ini menggunakan desain rancangan acak lengkap dengan tiga perlakuan pemberian dosis propolis dan dua perlakuan kontrol. Pembuatan ekstraksi dan sediaan propolis cair dilakukan di laboratorium Analisis Pangan, Politeknik Negeri Lampung, pemeliharaan hewan dilakukan di Rumah Sakit Hewan Pendidikan FKH IPB. Analisis fagositosis makrofag dilakukan di laboratorium Bakteriologi dan Imunologi Fakultas Kedokteran Hewan, IPB dan analisis nitrit oksida (NO) dan antibodi (IgG) dilakukan di Laboratorium Imunologi Pusat Studi Satwa Primata, LPPM IPB, Bogor. Penelitian ini dilaksanakan mulai bulan Januari hingga Desember 2016.

\section{Jumlah dan cara pengambilan sampel}

Penelitian ini menggunakan 25 ekor tikus, jumlah sampel dihitung berdasarkan rumus Frederer (1967), (t-1)(r-1) $>15$, dimana $\mathrm{t}=$ banyaknya kelompok perlakuan dan $\mathrm{r}=$ jumlah replikasi, menggunakan tiga perlakuan pemberian dosis propolis dan dua perlakuan kontrol sehingga masing-masing perlakuan terdiri atas lima ekor tikus. Tikus dipilih secara acak dibagi menjadi 5 kelompok, kelompok I pemberian $0,5 \%(\mathrm{v} / \mathrm{b})$ senyawa CAPE $20 \mathrm{mg} / \mathrm{kg}$ sebagai kontrol positif, yang memiliki efek sebagai imunomodulator (Park 2004). Kelompok II pemberian akuades (ad libitum) sebagai kelompok kontrol negatif, kelompok III, IV, dan V pemberian dosis propolis cair $0,16 \%, 0,48 \%, 1,44 \%$ dari bobot badan/hari.

Pertimbangan etik dalam pelaksanaan penelitian ini diperoleh dari Komisi Pengawasan Kesejahteraan dan Penggunaan Hewan Penelitian, Rumah Sakit Hewan Pendidikan, Fakultas Kedokteran Hewan, Institut Pertanian Bogor dengan Nomor: 2-2016 RSHP FKH-IPB tanggal 4 Januari 2016

\section{Alat dan bahan}

Peralatan yang digunakan antara lain kandang berukuran $50 \times 30 \times 20 \mathrm{~cm}$, botol air, maserator, magnetic stirer, evaporator merek Buchi Tipe-190. Alat untuk uji fagositosis makrofag dan uji NO yakni spuit injeksi $1 \mathrm{ml}, 3 \mathrm{ml}$, dan 10 $\mathrm{ml}$, sonde, pipa kapiler, tabung eppendorf, neraca elektronik (KERN ABT 220 SDM), alat sentrifus (SORVALL-LEGEND RT), inkubator $\mathrm{CO}_{2}$ $5 \% 37^{\circ} \mathrm{C}$, lempeng mikro (microplate) 24 sumur (Nunc), lempeng mikro 96 sumur (Nunc), coverslip plastik bulat (Thermanox) diameter $13 \mathrm{~mm}$, alat sentrifugasi, haemositometer, microplate reader (Bencmark BIO-RAD) $\lambda 550 \mathrm{~nm}$. Alat untuk uji respons antibodi yakni pipet volume 2 $\mu 1$ - $1 \mathrm{ml}$, pipet reagen 1-25 ml, silinder graduate $100 \mathrm{ml}$ dan 1 liter, kertas absorben, tabung reaksi standar dan sampel, kertas grafik log dan software data ELISA, dan microplate reader (Bencmark BIO-RAD) $\lambda 450 \mathrm{~nm}$.

Bahan penelitian berupa propolis mentah asal daerah Sulawesi Selatan yang diperoleh dari CV Nutrima Sehatalami, Bogor. Bahan untuk ekstraksi berupa etanol grade teknis dan bahan pengisi berupa propilen gilkol. Bahan untuk pemeliharaan tikus adalah pakan tikus, propolis cair 20\%, senyawa Caffeic Acid Phenethyl Ester (CAPE) C8221-Sigma-Aldrich, minyak jagung (Corn Oil-SIGMA C8267), dan air destilasi. Uji aktivitas fagositosis makrofag menggunakan bahan yakni kloroform, Free Hank's Balanced Salt solution, Medium Roswell Park Memoriam Institute (RPMI), etanol 70\%, akuabides, Phosphate Buffer Saline (PBS), akuades steril, glutamin, penisilin, streptomisin, Fetal Bovine Serum (FBS), metanol absolut, coverslips bulat, Gyemsa modified solution 20\%. Penetapan kadar NO menggunakan senyawa standar nitrit, reagen merah netral, serta larutan Griess A dan Griess B. Penetapan kadar IgG, menggunakan Mouse IgG EL1SA (ELM-IgG-RayBio ${ }^{\circledR}$ Mouse IgG).

Hewan uji yang digunakan berupa tikus putih Sprague Dawley berumur kurang lebih empat bulan (Andreollo et al. 2012) yang diperoleh dari Laboratorium Hewan Badan Pengawas Obat dan Makanan (BPOM), serta isolat bakteri Staphylococus aureus non protein A yang digunakan diperoleh dari laboratorium Bakteriologi dan Imunologi FKH, IPB.

\section{Tahapan penelitian}

Penelitian dimulai dengan pembuatan sediaan propolis cair, tahap pemeliharaan tikus dan intervensi perlakuan, dan tahap pengumpulan sampel terminal. Sediaan propolis cair diperoleh melalui ekstraksi propolis dari sarang lebah Trigona spp., dilakukan menggunakan metode Hasan et al. (2011). Sebanyak $150 \mathrm{~g}$ sarang lebah Trigona spp., dimaserasi dengan $650 \mathrm{ml}$ etanol $70 \%$ (direndam sambil digoyang menggunakan shaker) selama tujuh hari di dalam wadah erlenmeyer $1.000 \mathrm{ml}$. Setelah tujuh hari, filtrat didekantasi kemudian residu dimaserasi lagi dengan $50 \mathrm{ml}$ etanol 70\% yang baru. Proses ini dilakukan secara berulang setiap hari selama tujuh hari, hingga pelarut etanol pada residu tampak bening. Dengan demikian, total pelarut (etanol) yang digunakan adalah sebanyak $1.000 \mathrm{ml}$, dan total waktu maserasi selama 14 hari. Filtrat yang 
diperoleh diuapkan selanjutnya disatukan di dalam wadah gelap. Ekstrak propolis dilarutkan dengan propilen glikol dalam perbandingan 1:5 $(\mathrm{b} / \mathrm{b})$.

Kedua puluh lima ekor tikus hewan percobaan dikandangkan secara terpisah di dalam bak plastik berukuran $50 \times 30 \times 20 \mathrm{~cm}$ dengan tutup kawat yang mudah dibuka tutup, tiap kandang berisi dua ekor tikus. Alas kandang dialasi dengan sekam yang harus diganti tiap hari agar kondisi kandang tetap bersih. Selama penelitian semua kelompok tikus diberi pakan pelet AD-II sebanyak $10 \%$ dari berat badan. Pemberian minum dilakukan secara adlibitum. Pencucian bak kandang dilakukan tiga hari sekali. Kandang di-letakkan dalam ruangan yang memiliki ventilasi cukup dengan temperatur berkisar antara 25$28^{\circ} \mathrm{C}$ dan kelembaban berkisar antara $70-75 \%$. Penerimaan cahaya diatur 12 jam terang serta 12 jam gelap. Semua tikus hewan percobaan diaklimatisasi selama tujuh hari. Pemberian senyawa CAPE dan propolis cair dilakukan secara oral selama 14 hari sebelum tikus dinfeksi dengan $S$. aureus non protein A. Infeksi $S$. aures dilakukan pada hari ke-14 dengan menyuntikkan inokulum bakteri $S$. aureus dosis $1 \times 10^{9} \mathrm{cfu} / \mathrm{ml}$ secara intraperitoneal.

Pada hari ke-15 semua tikus pada masingmasing kelompok dilakukan euthanasia dengan eter dan diambil cairan peritoneum untuk pengujian aktivitas fagositosis makrofag (Wijayanti 2009) dan produksi NO menggunakan metode Griess (Dietert et al. 1995) serta pengambilan darah untuk pengujian produksi antibodi menggunakan ELISA (ELM-IgG-RayBio ${ }^{\circledR}$ Mouse IgG).

\section{Pengolahan dan analisis data}

Data yang diperoleh pada disajikan dalam rata-rata \pm standar deviasi. Semua analisa statistik dilakukan menggunakan Microsoft Excel dan SAS 9.1. Perbedaan yang signifikan antara perlakuan dianalisis menggunakan ANOVA, jika terdapat perbedaan nyata antar perlakuan dilakukan uji lanjut Duncan. Perbedaan secara signifikan dinyatakan dalam $\mathrm{p}<0,05$.

\section{HASIL DAN PEMBAHASAN}

Tikus jantan jenis Sprague Dawley yang digunakan dalam penelitian ini memiliki kisaran rata-rata berat badan awal (sebelum pemeliharaan) adalah 180-200 g/ekor. Berat badan ditimbang setiap satu minggu, pada akhir perlakuan dilakukan penimbangan berat badan sehingga diperoleh berat badan akhir dan dapat dihitung pe- rubahan berat badan tikus selama pemeliharaan. Secara umum semua kelompok perlakuan mengalami pertumbuhan yang baik, ditunjukkan oleh peningkatan berat badan (data tidak ditampilkan) dan tidak berbeda nyata antar grup perlakuan.

\section{Pengaruh propolis Trigona spp. terhadap ak- tivitas fagositosis makrofag}

Pengaruh propolis Trigona spp. terhadap kemampuan fagositosis makrofag dirangsang oleh perlakuan yang berbeda seperti yang ditunjukkan pada Gambar 1. Aktivitas fagositosis meningkat secara signifikan melalui pemberian dosis propolis yang berbeda $(0,16 \%, 0,48 \%$ dan $1,44 \%)$ sama dengan yang diamati pada CAPE (kontrol positif).

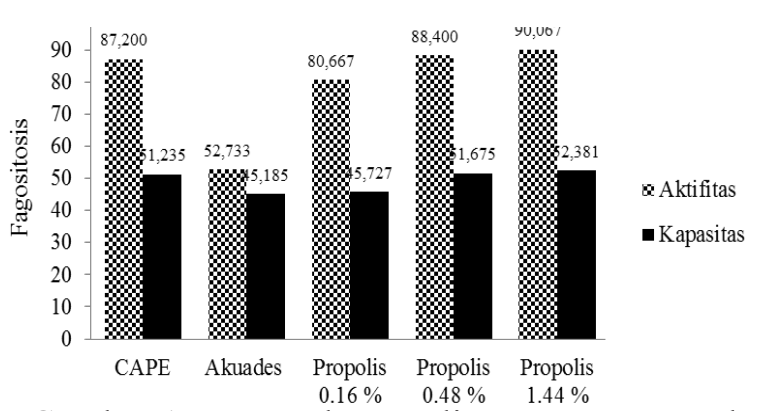

Gambar 1. Pengaruh propolis Trigona spp. terhadap kemampuan fagositosis makrofag

Makrofag merupakan komponen penting dalam imunitas bawaan. Makrofag berfungsi terutama sebagai sel fagosit dan mampu fagositosis organisme patogen. Selain itu, makrofag adalah produsen sitokin ampuh dan memainkan peran penting dalam berbagai proses, termasuk presentasi antigen dan penyembuhan luka. Terkait dengan peran makrofag sebagai penyaji antigen (APC), makrofag akan mengekspresikan MHC II pada permukaannya. Makrofag bersama-sama dengan MHC II menyajikan antigen kepada sel $\mathrm{T}$, ekspresi MHC II meningkat bila makrofag teraktivasi (Abbas et al. 2012).

Pemberian propolis sebagai imunomodulator memberikan pengaruh pada indeks fagositosis makrofag yang terlihat dari peningkatan kemampuan fagositosis makrofag pada pemberian propolis $0,16 \%$ dan menunjukkan sedikit peningkatan kemampuan fagositosis makrofag pada pemberian $0,48 \%$ bila dibandingkan dengan kontrol positif. Hal ini menunjukkan bahwa propolis sebagai imunomodulator berpotensi meningkatkan kemampuan fagositosis makrofag peritoneal tikus bila diberikan dalam jangka waktu tertentu, dan sedikit meningkatkan kemampuan fagositosis makrofag peritoneal bila diberikan dalam 
jumlah yang lebih tinggi. Hal ini dikarenakan sifat propolis sebagai imunomodulator dimana ketika diberikan dengan dosis kecil, dapat berpotensi meningkatkan kemampuan fagositosis makrofag (Takagi et al. 2005).

\section{Pengaruh propolis Trigona spp. terhadap produksi nitrit oksida (NO)}

Seperti yang ditunjukkan pada Gambar 2, propolis mampu meningkatkan produksi NO dalam makrofag oleh perlakuan pemberian dosis propolis yang berbeda. Produksi NO meningkat secara signifikan melalui pemberian dosis propolis yang berbeda $(0,16 \%, 0,48 \%$ dan $1,44 \%)$. Pada pemberian dosis $0,48 \%$ dan $1,44 \%$ berbeda secara bermakna dengan kelompok kontrol negatif dan kontrol positif serta kelompok dosis $0,16 \%$. Dalam penelitian ini, ditemukan bahwa pada pemberian propolis dosis $0,16 \%$ makrofag telah mampu menginduksi produksi NO.

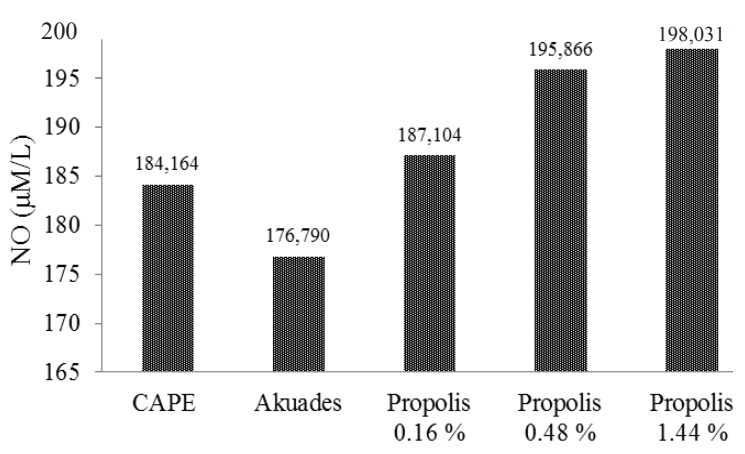

Gambar 2. Pengaruh propolis Trigona spp. terhadap produksi $\mathrm{NO}$

Hasil ini sesuai dengan penelitian lain yang menunjukkan bahwa NO memiliki peran regulasi penting dalam berbagai jenis proses inflamasi. Limonene dilaporkan dapat menekan produksi TNF- $\alpha$, sehingga menjadi agen antiinflamasi yang kuat terutama pada kondisi peradangan kulit (Yoon et al. 2010). Studi in vitro menunjukkan bahwa D-limonene meningkatkan produksi NO makrofag peritoneal pada tikus yang menderita tumor (Del Toro-Arreola et al. 2005).

Terpenoid pada ekstrak propolis menyebabkan aktivasi makrofag yang diikuti dengan diferensiasi dan proliferasi. Proses diferensiasi dan proliferasi ini menyebabkan peningkatan jumlah makrofag yang beredar di dalam tubuh (Abbas et al. 2012). Namun penelitian Kang et al. (2011) menunjukkan asam lipoteikoat (LTA) pada bakteri gram positif tidak dapat menginduksi produksi NO pada cell line makrofag RAW 264.7 kecuali jika terdapat interferon gamma (IFN- $\gamma$ ) yang dapat meningkatkan aktivitas pengikatan
DNA dari faktor transkripsi NF- $\kappa B$ yang diketahui terlibat pada ekspresi gen iNOS. Menurut Farooqui dan Farooqui (2010), komponen propolis seperti quercetin, CAPE maupun terpenoid, diduga dapat menghambat terbentuknya peroksinitrit $\left(\mathrm{NO}_{2}^{-}\right)$penyebab kerusakan sel. Propolis tidak hanya menekan pembentukan prostaglandin dan leukotrien dengan menghambat ekspresi dan aktivitas cyclooxygenase dan lipoxygenase, tetapi juga memperlambat ekspresi gen nitrat oksida sintase, aktivasi NF- $\kappa \mathrm{B}$ yang dimediasi TNF- $\alpha$. Penghambatan aktivasi NF- $\kappa$ B ini dapat menjadi dasar molekuler sifat anti inflamasi dari propolis.

Hal ini sangat berbeda dengan hasil penelitian Buffalo et al. (2013), yang menunjukkan bahwa pemberian ekstrak propolis dan asam caffeic $(5,10,25,50$ and $100 \mu \mathrm{g} / \mathrm{ml})$ mampu menghambat produksi NO dalam cell line makrofag (raw 264.7 cells), selanjutnya mampu menekan jalur sinyal yang disebabkan LPS, yaitu p38 MAPK, JNK1/2 dan NF-kB. Demikian juga menurut Márquez et al. (2004), pemberian senyawa CAPE $(1,5$ dan $10 \mu \mathrm{M})$ memiliki efek penghambatan terhadap faktor transkripsi NF$\kappa B$ dan NFAT dan akibatnya, CAPE dapat menghambat transkripsi gen IL-2, ekspresi IL-2R (CD25), dan proliferasi sel $\mathrm{T}$ pada manusia.

Dugaan kuat senyawa terpenoid yang dikandung propolis Trigona spp. pada penelitian ini seperti limonene, mampu bekerja mengaktifkan makrofag. Berbeda dengan hasil penelitian Halim et al. (2012) yang memperoleh senyawa bioaktif utama propolis Indonesia yaitu cyclolanost, fenol derivat, $\alpha$-amyrin, senyawa eudesmane, senyawa etil acridin, senyawa lupeol, senyawa friedooleanan, dan senyawa pirimidin, yang berperan sebagai antioksidan dan antihiperglikemik. Beberapa penelitian lain telah menunjukkan bahwa beberapa bahan dalam propolis, seperti caffeic acid phenethyl ester, asam sinamat, dan artepillin $\mathrm{C}$, juga mampu mengaktifkan makrofag secara in vitro dan in vivo (Gao et al. 2014). Data literatur menunjukkan bahwa minyak esensial dari Eucalyptus globulus, yang mengandung $p$-cymene yang merupakan anggota monoterpene, juga mampu merangsang respons fagositosis makrofag serta $p$-cymene juga dapat merangsang fagositosis melalui pengikatan dengan reseptor TLR4 (Kummer et al. 2015).

Salah satu indikasi makrofag teraktivasi adalah terbentuknya nitrit oksida (NO) dari Larginin oleh nitric oxide synthase (NOS). Nitrit oksida merupakan radikal bebas yang berupa gas anorganik dan bersifat dapat menembus lapisan membran. NO berperan penting pada berbagai 
fungsi fisiologis salah satunya adalah sebagai mediator kunci pada imunitas non spesifik. NO bersifat toksik terhadap bakteri patogen karena NO dapat menghambat enzim ribonukleotida reduktase dan mengganggu sintesis DNA. NO juga dapat menginaktivasi enzim yang berikatan dengan zat besi dan sulfur seperti Nicotinamide Adenine Dinucleotide (NADH) dan ubikuinon oksidoreduktase. Meskipun NO sendiri bersifat cukup toksik dan secara alami sifatnya reaktif, tapi NO dapat dengan mudah berikatan dengan molekul lain seperti oksigen dan menghasilkan nitrat dan nitrit yang bersifat stabil dan tidak toksik (Billack 2006).

\section{Pengaruh propolis Trigona spp. terhadap produksi antibodi}

Pengaruh pemberian perlakuan propolis Trigona spp. yang berbeda mampu merangsang produksi antibodi oleh seperti ditunjukkan pada Gambar 3. Pemberian ekstrak propolis ini meningkatkan potensi respons imun humoral bila dibandingkan dengan hewan yang menerima antigen tanpa propolis (kontrol negatif). Produksi antibodi $\operatorname{IgG}$ meningkat secara signifikan dengan konsentrasi propolis yang berbeda $(0,16 \%$, $0,48 \%$ dan $1,44 \%$ ). Perlakuan pemberian propolis $0,48 \%$ tidak berbeda nyata bila dibandingkan dengan pemberian CAPE (kontrol positif). Kandungan IgG serum meningkat secara dramatis pada tikus yang menerima $0,48 \%$ propolis $T r i$ gona spp. dibandingkan dengan pemberian perlakuan lain $(0,16 \%$ dan $1,44 \%)$.

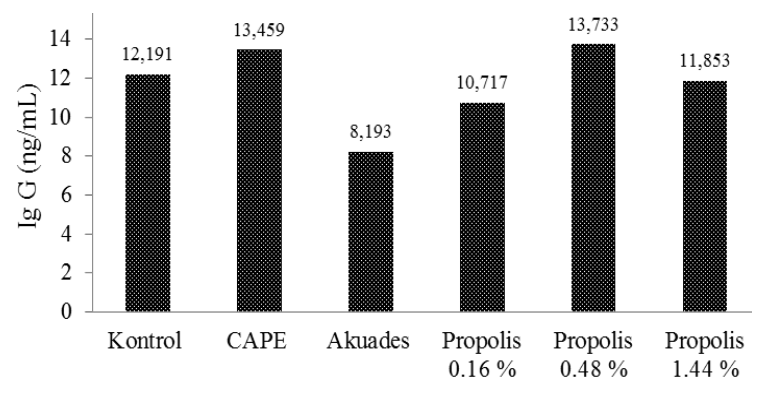

Gambar 3. Pengaruh propolis Trigona spp. terhadap produksi antibodi sebelum dan sesudah intervensi

Gambar 3 juga menunjukkan bahwa rerata produksi antibodi (IgG) akibat pengaruh pemberian ketiga dosis propolis terdapat peningkatan secara bermakna dibandingkan dengan kelompok kontrol negatif (akuades). Terlihat juga terjadi peningkatan produksi IgG sebelum dan sesudah intervensi pada kelompok perlakuan pemberian propolis $0,48 \%$ dan kontrol positif (CAPE), meskipun peningkatan ini secara statistik tidak berbeda nyata. Terjadi penurunan pada kelompok perlakuan pemberian propolis $0,16 \%$ dan $1,44 \%$ maupun pada kelompok kontrol negatif (akuades). Pemberian dosis yang melebihi dosis efektif dapat bersifat toksik, sehingga pemberian ekstrak propolis Trigona spp. yang melebihi dosis maksimal ini menyebabkan terjadinya pengurangan ekspresi respons imun karena mekanisme imunosupresan dari sistem imun tersebut.

Adanya infeksi $S$. aureus pada hewan yang makrofagnya telah teraktivasi menyebabkan makrofag bergerak ke arah sumber infeksi. Makrofag yang sudah sampai di tempat infeksi akan melakukan fagositosis terhadap $S$. aureus. Selanjutnya kuman diproses di dalam fagolisosom menjadi fragmen-fragmen peptida. Fragmen peptida yang terbentuk diikat oleh major histocampactibility complex (MHC) dan dibawa ke permukaan sel untuk disajikan ke sel T. Selama fagositosis dan pemrosesan antigen, makrofag mengeluarkan beberapa sekresi, salah satunya adalah IL-2. Infeksi S. aureus pada saat makrofag sedang teraktivasi, menyebabkan fagositosis berjalan sempurna, sehingga fragmen antigen dari $S$. aureus disajikan keluar sel bersama protein $\mathrm{MHC}$ II dalam bentuk kompleks peptida MHC. Kompleks peptida $\mathrm{MHC}$ ini akan berinteraksi dengan sel-T helper melalui reseptornya. Selanjutnya sel $\mathrm{T}$ helper menjadi aktif dan mensekresikan IL-2. Sekresi IL-2 oleh sel-T helper akan berakibat pada aktivasi sel B. Aktivasi sel B ditandai oleh proliferasi dan diferensiasi sel B menjadi sel plasma secara berulang-ulang, sehingga terjadi peningkatan sel plasma di dalam tubuh. Selanjutnya sel plasma ini akan menghasilkan antibodi terhadap bahan asing tersebut (Baratawidjaja 2014).

\section{KESIMPULAN}

Penelitian ini menunjukkan bahwa pemberian ekstrak etanol propolis cair Trigona spp. pada hewan coba tikus mampu mengindikasikan makrofag hewan tikus telah teraktivasi melalui peningkatan kemampuan fagositosis makrofag dan peningkatan produksi nitrit oksida dan meningkatkan produksi antibodi. Produksi antibodi tertinggi diperoleh pada perlakuan pemberian propolis $0,48 \%$. Kombinasi hasil ini menunjukkan bahwa ekstrak ini memiliki efek imunomodulator dan mampu meningkatkan respons imun.

Pemanfaatan propolis cair Trigona spp. sebagai herbal untuk memperbaiki sistem imun perlu digalakkan dan masih diperlukan penelitian lebih lanjut tentang uji klinis propolis cair Trigona spp.

J. Gizi Pangan, Volume 12, Nomor 1, Maret 2017 


\section{UCAPAN TERIMA KASIH}

Ucapan terima kasih ditujukan kepada Kemenristek DIKTI yang telah membantu dalam pendanaan penelitian ini dan Bpk Mahani yang telah membantu dalam pengadaan sampel propolis.

\section{DAFTAR PUSTAKA}

Abbas AK, Lichtman AH, Pillai S. 2012. Cellular and molecular immunology. $7^{\text {th }}$ ed. Philadelphia: Saunders Elsevier.

Bankova VS. 2009. Chemical diversity of propolis makes it a valuable source of new biologically active compounds. J Api Prod Api Med Sci 1(2):23-28.

Baratawidjadja KG. 2014. Imunologi dasar. edisi 11. Jakarta: FKUI.

Billack B. 2006. Macrophage activation: role of toll-like 24 receptors, nitric oxide, and nuclear factor kappa B. Am J Pharmaceutical Edu. 70(5):1-10.

Buffalo MC, Ferreira I, Costa G, Fansisco V, Liberal J, Cruz TM, Lopes MC, Batista MT, Sforcin JM. 2013. Propolis and its constituent caffeic acid suppress LPS-stimulated pro-inflammatory responsse by blocking $\mathrm{NF}-\mathrm{\kappa B}$ and MAPK activation in macrophages. J Ethnopharmacol149(1):84-92.

Del Toro-Arreola S, Flores-Torales E, TorresLozano C, Del Toro-Arreola A, TostadoPelayo K, Guadalupe Ramirez-Dueñas M, Daneri-Navarro A. 2005. Effect of Dlimonene on immune responsse in BALB/c mice with lymphoma. Int Immunopharmacol 5(5):829-838.

Dietert RR, Hotchkiss JH, Austic RE, Sung Y. 1995. Production of reactive nitrogenc intermediates by macrophages. In: Burleson GR, Dean JH, Munson AE. A John, editor. Methodes in Immnunotoxicology. Volume 2. New York: Wilye Liss \& sons Inc Publ.

Farooqui T dan Farooqui AA. 2010. Molecular mechanism underlying the therapeutic activities of propolis: A critical review. Curr Nutr Food Sci 6(3):186-199.

Frederer WT. 1967. Experimental design: theory and application. Calcutta: Oxford \& IBH Publ Co.

Gao W, Wu J, Wei J, Pu L, Guo C, Yang J, Yang M, Luo H. 2014. Brazilian green propolis improves immune function in aged mice. $\mathrm{J}$ Clin Biochem Nutr 55(1):7-10.

Hasan AEZ, Artika IM, Fatoni A. 2011. Antibacterial activity of propolis Trigona spp. from
Bukittinggi, West Sumatera against Salmonella sp. Chem Progress 4(2):55-59.

Halim E, Sutandyo N, Sulaeman A, Artika M, Harahap Y. 2012. Kajian bioaktif dan zat gizi propolis Indonesia dan Brasil. J Gizi Pangan 7(1):1-6.

Kang SS, Ryu YH, Baik JE, Yun CH, Lee K, Chung DK, Han SH. 2011. Lipoteichoic acid from Lactobacillus plantarum induces nitric oxide production in the presence of interferon- $\gamma$ in murine macrophages. Mol. Immunol 48(15-16):2170-2177.

Krol W, Czuba Z, Scheller S, Gabrys J, Grabiec S, Shani J. 1994. Anti-oxidant properties of ethanolic extract of propolis (EEP) as evaluated by inhibiting the chemiluminescence oxidation of luminal. Biochem Int 21(4):593-597.

Kumazawa S, Hamasaka T, Nakayama T. 2004. Antioxidant activity of propolis of various geographic origins. Food Chem 84(3):329339.

Kummer R, Estevão-Silva CF, Bastos RL, Grespan R, de Souza Silva-Comar FM, Spironello RA, Rocha BA, Bersani-Amado CA, Cuman RKN. 2015. Effect of p-cymene on chemotaxis, phagocytosis and leukocyte behaviors. Int J Appl Res Nat Prod 8(2): 20-27.

Marcucci MC, Ferreres F, Garcia-Viguera C, Bankova VS, De Castro SL, Dantas AP, Valente PHM, Paulino N. 2001. Phenolic compounds from Brazilian propolis with pharmacological activities. J Ethnopharmacol 74(2):105-112.

Márquez N, Sancho R, Macho A, Calzado MA, Fiebich BL, Mũnoz E. 2004. Caffeic acid phenethyl ester inhibits T-cell activation by targeting both nuclear factor of activated T-cells and NF- $\kappa \mathrm{B}$ transcription factors. $\mathrm{J}$ Pharmacol Exp Ther 308(3):993-1001.

Mihai CM, Marghitas LA, Dezmirean D, Barnutiu L. 2011. Correlation between polyphenolic profile and antioxidant activity of propolis from Transylvania. Anim Sci Biotech 44(2):100-103.

Naga PN, Rajeshwari P. 2014. An overview on immunomodulators. Int J of Curr Pharmaceutical \& Clinical Research 4(2): 108-114.

Nathan C, Xie QW. 1994. Nitric oxide synthases: roles, tolls, and controls. Cell 78(6):915918.

Noss EH, Pai RK, Sellati TJ, Radolf JD, Belisle J, Golenbock DT, Boom WH, Harding CV. 2001. Toll-like receptor 2-dependent in- 
Kalsum dkk.

hibition of macrophage class II MHC expression and antigen processing by $19-\mathrm{kDa}$ lipoprotein of M. tuberculosis. J Immunol 167(2):910-918.

Papanicolaou DA. 2000. Interleukin-6: Endocrine cytokine. J Clin Endocrinol Metab 85(3):1331-1333.

Park JH, Lee JK, Kim HS, Chung ST, Eom JH, Kim KA, Chung SJ, Paik SY, Oh HY. 2004. Immunomodulatory effect of caffeic acid phenethyl ester in Balb/c mice. Int Immunopharmacol 4(3):429-436.

Rieux-Laucat F, Fischer A, Le Deist F. 2003. Cell-death signaling and human disease. Curr Opin Immunol 15(3):325-331.

Sforcin JM. 2007. Propolis and the immune system: a review. J Ethnopharmacol 113(1):114.

Sforcin JM, Fernandes Júnior A, Lopes CAM, Bankova V, Funari SRC. 2000. Seasonal effect on Brazilian propolis antibacterial activity. J Ethnopharmacol 73(1):243-249.

Silva JC, Rodrigues S, Féas X, Estevinho LM. 2012. Antimicrobial activity, phenolic profile and role in the inflammation of propolis. Food Chem Toxicol 50(5):1790-1795.

Takagi Y, Choi I, Yamashita T, Nakamura T, Suzuki I, Hasegawa T, Oshima M, Gu Y. 2005. Immune activation and radioprotection by propolis. Institute for Advance Research in Asian Science and Medicine. Am J Chin Med. 33(3):231-240.

Yoon WJ, Lee NH, Hyun CG. 2010. Limonene suppresses lipopolysaccharide-induced production of nitric oxide, prostaglandin $\mathrm{E}$ and pro-inflammatory cytokines in RAW 264.7 macrophages. J Oleo Sci 59(8):415421.

Wijayanti M. 2009. Isolasi Makrofag dan Uji Daya Fagositosis. Yogyakarta: UGM Press. 